\title{
Kesalahan Berbahasa Tataran Morfologi Bahasa Indonesia dalam Makalah Mahasiswa Pendidikan Bahasa Indonesia Semester 2 (Dua) Universitas Nahdlatul Ulama Blitar
}

\author{
Nur Holifatuz Zahro(1), Agus Hermawan ${ }^{(2)}$ \\ ${ }^{1}$ Progam Studi Pendidikan Guru Sekolah Dasar, Indonesia \\ ${ }^{2}$ Progam Studi Pendidikan Bahasa Indonesia, Indonesia \\ Email: ${ }^{1}$ nur holifatuz zahro@unars.ac.id, ${ }^{2}$ agushermawan8992@gmail.com
}

\begin{abstract}
Abstrak: Kesalahan berbahasa merupakan kesalahan berbahasa yang terjadi dalam penulisan secara resmi atau formal misal makalah, laporan penelitian : skripsi, tesis dan disertasi. Dalam perkembangan bahasa Indonesia sebagai salah satu mata pelajaran disekolah sampai perguruan tinggi yang merupakan mata pelajaran dan mata kuliah yang bersifat umum, sehingga dalam proses penyampaiannya tidak hanya dalam proses belajar-mengajar akan tetapi di tuntut secara luas untuk mengembangkannya melalui berbagai tulisan secara ilmiah dan non

\begin{tabular}{l} 
Tersedia Online di \\
http://journal.unublitar.ac.id/pendidikan/index \\
php/Riset Konseptual \\
\hline Sejarah Artikel \\
Diterima pada $: 27-07-2021$ \\
Disetuji pada : 29-07-2021 \\
Dipublikasikan pada $: 31-07-2021$
\end{tabular}

\section{Kata Kunci:}

Kesalahan Berbahasa, Morfologi, Makalah DOI:

http://doi.org/10.28926/riset_konseptual.v5i3.394

ilmiah. Untuk mencapai tujuan bersama dalam pembinaan dan pengajaran Bahasa hendaknya guru dan dosen memberikan latihan pada siswa maupun mahasiswa dalam konteks menulis makalah ilmiah dan mengoreksi tulisannya agar mahasiswa memahami penggunaan Bahasa yang baik dan benar. Pembelajaran Bahasa Indonesia di perguruan tinggi sangat berpengaruh terhadap keberlanjutan pembinaan Bahasa Indonesia Kita.
\end{abstract}

\section{PENDAHULUAN}

Manusia sebagai mahluk social yang selalu membutuhkan orang lain dalam berbahasa melakukan komunikasi dengan sesama melalui bentuk tulis maupun lisan. Alat ucap berupa bunyi bunyi yang digunakan untuk menyampaikan pikiran dan perasaan itulah yang disebut Bahasa Bahasa. Hal tersebut selaras dengan pernyataan Keraf (2001:1) bahwa Bahasa adalah alat komunikasi antara anggota masyarakat berupa simbol bunyi yang dihasilkan oleh alat ucap manusia.

Bahasa sebagai alat komunikasi lisan maupun tulis. Dapat diartikan bahwa Bahasa berfungsi sebagai alat komunikasi baik lisan maupun tulis. Artinya bahwa Bahasa adalah suatu alat untuk mengungkapkan pikiran, perasaan, dan kemauan yang murni manusiawi dan tidak insingtif, dengan pertolongan system lambinglambang yang diciptakan dengan sengaja. (Prastyaningsih, 2001: 22). Penyampaian informasi atau pesan tersebut tentunya dengan menggunakan kalimat. Maka, agar pesan yang disampaikan oleh penutur dapat diterima oleh penerima perlu diperhatikan penyusunan kalimat efektif. Dalam dunia pendidikan formal maupun non formal.

Pengajaran Bahasa di sekolah-sekolah di samping menumbuhkan penguasaan Bahasa Indonesia juga untuk menanamkan kesadaran kepada siswa. Bahasa Indonesia harus benar-benar dipelihara, dihargai setinggi-tingginya, dan harus sanggup dipakai dalam mendukung kebudayaan nasional dalam arti yang luas. Berkenaan dengan sering terjadi kesalahan berbahasa dalam pengajaran Bahasa Indonesia di sekolah, perlu mendapatkan penanganan pembinaan yang sungguhsungguh. Bertolak dari hal itu, penyimpangan kaidah Bahasa Indonesia harus dihindari dan sedapat mungkin bisa ditanggulangi dengan melaksanakan pembinaan secara 
intensif terhadap Bahasa Indonesia di sekolah maupun perguruan tinggi. Untuk itu, informasi tentang kemampuan mahasiswa dan penguasaan kemampuan berbahasa merupakan suatu hal penting. Sesuai dengan pendapat diatas tentang pembinaan dan pengembangan Bahasa Indonesia, Widyamartaya (2006:44) mengemukakan hal-hal yang perlu dibina dan dikembangkan meliputi pelafalan, ejaa, kosa kata dan tata bahasa. Keempat hal tersebut merupakan materi terpenting dalam pembinaaan dan pengembangan Bahasa sehingga dapat menggunakan kaidah dengan baik dan benar.

Dalam usaha mendapatkan informasi tersebut, perlu adanya penelitian tentang kemampuan mahasiswa dalam penggunaan Bahasa Indonesia termasuk di dalamnya penelitian tentang analisis kesalahan berbahasa yang terjadi dalam proses belajar Bahasa Indonesia siswa khususnya dalam kemampuan menulis makalah.

\section{METODE}

Penelitian di katakan ilmiah jika metode yang dipakai sesuai cara kerja dan disusun secara bersistem untuk memudahkan pelaksanaan penelitian. Penelitian merupakan kegiatan ilmiah. Sebagai kegiatan ilmiah penelitian membutuhkan metode. Metode merupakan syarat yang penting karena sangat berpengaruh terhadap ketepatan pencapaian dan tujuan dan keberhasilan penelitian. Suatu metode dipilih dengtan pertimbangan sesuai dengan objek yang diteliti. Pemilihan metode yang tepat dan sesuai akan menunjang keberhasilan penelitian.

Dalam metode ini digunakan metode kualitatif. Hal ini didasarkan atas dua pertimbangan, pertama peneitian ini didasarkan pada faktabahwa data peneitian ini berdasarkan pada fakta bahwa data penelitian ini berupa data kualitatif. Kedua tujuan dari penelitian ini berusaha mendeskripsikan kesalahan berbahasa pada Bahasa tulis mahasiswa dalam makalah mahasiswa semester dua. Hal ini sesuai dengan pendapat Moleong (2011:6), "penelitian kualitatif adalah penelitian yang bermaksud untuk memahami fenomena tentang apa yang dialami oleh subyek penelitian dan dilakukan secara deskripsi dalam bentuk kata-kata dari bahasa pada suatu konteks khusus yang alamiah".

Penelitian kualitatif bersifat deskriptif adalah penggambaran data yang menghasilkan data deskriptif yang berupa kata-kata. Dalam hal ini tentunya metode kualitatif lebih tepat digunakan dalam penelitian ini, yaitu analisis kesalahan berbahasa pada Bahasa tulis atau bentukan kata dalam makalah mahasiswa semester dua pendidikan Bahasa Indonesia.

Penelitian lahir karena ada problem yang hendak dipecahkan. Problem penelitian sering disebut objek penelitian, yaitu sesuatu yang menjadi pusat permasalahan. Berkenaan deng ahal tersebut Sudaryantu berpendapat " Objek penelitian adalah suatu yang terjadi dari pengamatan dalam penelitian atau data sebagai bahan penelitian". Mahsun (2007:18). Peneliti sebagai aktivitas ilmiah dituntut memiliki bukti empiris atau factual. Dengan kata lain, peneliti memerlukan data yang valid dan objektif. Data adalah segala fakta dan angka yang dijadikan bahan untuk menyusun suatu informasi.

Dalam penelitian ini, data berupa unit kebahsaan berupa kata-kata, frasa atau kalimat yang ada dalam makalah mahasiswa yang menggambarkan bentuk reduplikasi dan afiksasi. Kualitis penelitian salah satunya ditentukan oleh kualitas data. Kualitas data ditentukan kejelasan asal-usul data dan sumber data. Lofland dan Lof-land menyatakan bahwa sumber utama dalam penelitian kualitatif adalah kata-kata dan tindakan selebihnya adalah data tambahan seperti dokumen dan lain-lain. (Moleong, 2011:112) Sebagaimana diketahui bahwa objek penelitian ini adalah penelitian kesalahan berbahasa tataran morfologi bahasa indonesia dalam makalah mahasiswa pendidikan bahasa indonesia semester 2 (dua).

Teknik pengumpulan data adalah cara untuk mengambil data secra objektif, jelas, dan benar. Pengumpulan data penelitian ini menggunakan teknik simak dan teknik catat. Teknik simak diperlukan terhadap data berupa bahan dalam teks atau naskah (Sudaryanto, 1988:2) adapun teknik catat merupakan cara yang dilakukan 
peneliti untuk mencatat secara langsung data dari naskah tersebut( Sudaryanto, 1988:5). Metode simak dibagi menjadi empat (1) teknik sadap, (2) teknik simak libat cakap, (3) tunjuk catat, (4) teknik rekam (Mahsun, 2011:92-93). Teknik pengumpulan data yang digunakan dalam penelitian ini adalah teknik simak dan teknik catat yang dianggap relevan dengan metode yang digunakan. Hal ini dilakukan dengan cara pencatatn yang sistematis terhadap data tersebut. Adapun langkah-langkah untuk mengumpulkan data dalam penelitian ini adalah:

1. Membacakan kumpulan makalah mahasiswa semester dua dengan teliti dan menyeluruh;

2. Membaca ulang umpulan makalah mahasiswa semester dua mengidentifikasi unsur reduplikasi dan afiksasi yang terdapat dalam kumpulan makalah;

3. Mencatat calon data kedalam kartu data sesuai dengan aspek yang diteliti berupa reduplikasi dan afiksasi

4. Mengklasifikasi data berdasarkan aspek yang di teliti reduplikasi dan afiksasi.

Instrument penelitian Menurut Moleong (2010:103) bahwa penelitin yang digunakan human instrumen berarti peneiti bertindak sebagai perencana, pelaksana, pengumpul data, analisis, penafsiran data, dan pada akhirnya melaporkan hasil penelitian.

Penelitian ini merupakan penelitian kualitatif, maka instrument atau alat pengumpulan data yag digunakan adalah peneliti sebagai instrument kuci. Selanjutnya, untuk mempermudah pengambilan data peneliti juga menggunakan intrumen pembantu berupa kartu data. Hal inidilakukan agar data tidak menyimpang dari kajian teori.

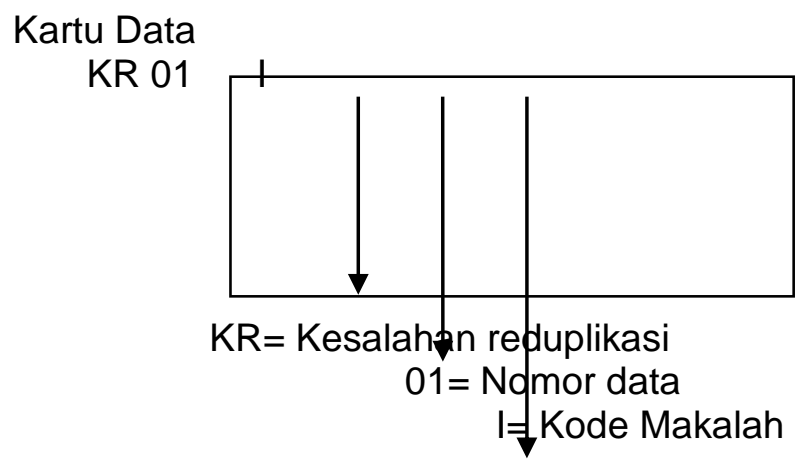

Contoh:

(01) Sebagai masyarakat yang baik harus rajin Tolong-mentolong

\section{Tolong-Mentolong (KR/01/IV-V)}

Analisi data adalah upaya yang dilakukan dengan jalan bekerja dengan data, mengorganisasi data, memilah-milahnya menjadi satu satuan yang dikelola, mensistensiskannya, mencari dan menemukan pola menemukan apa yang penting dana pa yang dipelajari dan memutuskan apa ynag dapat diceritakan kepada orang lain, bogdan dan biklen (Moelong, 2005:248) Teknik analisi data dalam penelitian ini adalah teknik analisis deskriptif, karena data yang dikumpulkan berupa uraian kata-kata dan bukan berupa angka. Teknik anaisis data deskriptif digunakan untuk mendeskripsikan kesalahan berbahasa dalam makalah mahasiswa. Adapun langkah-langkah analisis data penelitian ini sebagai berikut:

1. Membaca secara intensif dan berulang-ulang kajian teori pada penelitian ini serta semua literatur yang mendukung objek penelitian \;

2. Mengidentifikasi aspek 1) kesalahan reduplikasi 2) kesalahan afiksasi. Setelah teridentifikasi satu persatu lalu diberi tanda aspek-aspek tersebut; aspek 1) kesalahan reduplikasi 2) kesalahan afiksasi. 
3. Mengklasifikasikan data sesuai dengan Menganalisis dan mendeskripsikan data yang telah terklarifikasi berdasarkan data aspek 1) kesalahan reduplikasi 2) kesalahan afiksasi.

4. Menyimpulkan dan menyajikan hasilnya dalam bentuk uraian yang sistematis.

\section{HASIL dan PEMBAHASAN \\ Kesalahan Berbahasa dalam tataran morfologi bahasa indonesia}

Morfologi adalah ilmu yang mempelajari seluk beluk pembentukan kata, menurut ramlan (2012:21) morfologi adaah bagian dari ilmu bahasa yang membicarakan atau yang mempelajari seluk beluk bentuk kata serta pengaruh perubahan-perubahan bentuk kata itu, baik itu fungsi gramatika maupun fungsi semantik. Ada tiga macam bentuk kata yang terjadi akibat proses morfologis. Ketig bentuk kata itu adalah kata yang berimbuhan, kata ulang, dan kata majmuk. Kata berimbuhan adalah kata yang terbentuksebagai akibat dari proses afiksasi. Kata ulang adalah kata yang terbentuk akibat proses reduplikasi. Kata majmuk adalah kata yang terbentuk akibat dari proses komposisi. Itu, menurut Ghufron (2015:110) kesalahan berbahasa dalam bidang morfologi dikelompokkan menjadi kesalahan afiksasi, kesalahan reduplikasi, dan kesalahan komposisi. Berikut pembahasan kesalahan berbahasa dalam tataran morfologi: 1) kesalahan penentuan bentuk asal. 2) kesalahan pengekalan fonem dalam proses afiksasi, 3) kesalahan dalam bentuk reduplikasi.

a) Kesalahan penentuan bentuk asal.

Kesalahan berbahasa pada tataran afiksasi bisa disebabkan oleh kesalahan penentuan bentuk asal. Kata meribah merupakan kata bentukan yang salah sebagai akibat dari kesalahan penentuan bentuk asal. Kata bentukan yang benar adalah mengubah. Kata yang dibawah fonem /u/ seperti kata ubah jika mendapatkan awalan meng- akan tetap meng-, bukan mer-. Jadi, kita bentukan yang tepat

Berikut data Kesalahan Penetuan Bentuk Asal:

01. Sehingga dengan mentambah wawasan, rasa cinta pada tanah air dalam masyarakat luas dan mendidi....KBA/01/MK1

02.Sering mentimbulkan pandangan yang mengabaikan semua mitos dalam pencarian sistem ilmiah....KBA/02/MK2

03. Karya yang terbit sebelum tahun 1928- yang lazim nolong - yang lazim mengolongkan pada sastra Angkatan '20 atau angkatan Balai Pustaka KBA/03/MK3

04. Perkembangan kesusastraan Indonesia modern tidak bisa memisahkan dari keberadaan Balai Pustaka yang awalnya adalah Komisi untuk Bacaan Sekolah Pribumi dan Bacaan Rakyat...KBA/04/MK4

05. Pendapat Bakri Siregar dipertegas Jacob Sumarjo yang mengatakan bahwa sastra Balai Pustaka tidak muncul dari masyarakat Indonesia secara bebas dan spontan, tetapi dimunculkan....KBA/05/MK4

06. Penyataan sikap seniman dan sastrawan indonesia Indonesia di Jakarta pada 17 Agustus 1963 tentang pendirian dan cita-cita politik nasional. Para penandatangan Manifes Kebudayaan menyuarakan....KBA/06/MK5

07. Arief Budiman memang dikenal dengan pandangan-pandangannya yang sangat kritis. la tidak hanya mengugat universalitas sosiologi dan 
ekonomi-politik, tapi juga sastra....KBA/07/MK5

Pada Data Kesalahan Penetuan Bentuk Asal (01), (02), (03), (04), (05), (06) dan (07) terdapat proses kesalahan bentuk asal yang kurang sesuai maka dari itu ada beberapa tataran afiksasi bisa disebabkan oleh kesalahan penentuan bentuk asal dan merupakan kata bentukan yang salah sebagai akibat dari kesalahan penentuan bentuk asal.

b) Kesalahan dalam pembentukan reduplikasi

Kesalahan berbahasa dalam tataran reduplikasi disebabkan oleh hal-hal berikut: kesalahan pembentukan, kesalahan penulisan, dan kesalahan makna.

Berikut data Kesalahan pembentukan reduplikasi:

01. Perbedaan tersebut juga meandang peristiwa atau persoalan yang kaitannya dengan kehidupan sastra.... KBR/01/MK2

02. Balai Pustaka didirikan pada masa itu untuk meproduksi bahan bacaan bagi sekolah yang dibangun oleh pemerintah kolonial Belanda diyakini sebagai bagian dari Politik Etis atau Politik Balas Budi....KBR/02/MK2

03. Propaganda militer mulai disebarkan, dan menserukan pembersihan di seluruh negeri. Propaganda ini berhasil meyakinkan orang-orang Indonesia dan pemerhati internasional bahwa dalang dari semua peristiwa ini adalah $\mathrm{PKI}$....KBR/03/MK3

04. Novel pop mesajikan secara baik dan ada pula yang disajikan tidak baik. Dan tujuannya adalah menghasilkan sesuatu yang bersifat materi...KBR/04/MK3

05. Novel ini becerita tentang masa muda Selena yang nantinya akan menjadi guru matematika kesayangan Raib, Seli, dan Ali di dunia Klan Bumi....KBR/05/MK4

06. Novel Selena akan mejelaskan beberapa hal yang menjadi pertanyaan pembaca pada seri Bumi sebelumnya....KBR/06/MK4

07. Tetapi pendapat lai beranggapan berbeda sehingga peristiwa tersebut tidak perlu menjadi catatan dalam pekembangan kesastraaan Indonesia....KBR/07/MK5

08. Kaum pergerakan memandang bacaan sebagai bagian yang tak terpisahkan dari mesin pegerakan untuk mengikat dan menggerakkan kaum buruh dan kaum tani....KBR/08/MK5

09. Ketika organisasi-organisasi radikal oleh dilarang Belanda, terjadi pula perlarangan produksi bacaan liar....KBR/09/MK5

10. Pada awalnya pemerintah kolonial tidak begitu keras menhalangi produksi bacaan liar, dalam pengertian tidak dilakukan pelarangan tehadap produksi bacaan liar....KBR/10/MK5

Pada Data pembentukan reduplikasi (01), (02), (03), (04), (05), (06), (07), (08), (09) dan (10) terdapat proses kesalahan bentuk asal yang kurang sesuai maka dari itu ada beberapa tataran afiksasi bisa disebabkan oleh tataran reduplikasi disebabkan oleh hal-hal berikut: kesalahan pembentukan, kesalahan penulisan, dan kesalahan makna. 


\section{KESIMPULAN}

Berdasarkan hasil penelitian, dapat disimpulkan bahwa ditemukan bentuk kesalahan pembentukan kata dan kesalahan bentuk reduplikasi dalam makalah mahasiswa semester 2.

Bentuk pertama ada 7 kesalahan pembentukan kata dan ada 10 kesalahan reduplikasi. Berdasarkan simpulan penelitian ini dapat berguna pihak terkait penelitian ini. Diantaranya, bagi mahasiswa Pendidikan Bahasa dan Sastra Indonesia maupun mahasiswa Program Studi lain diharapakan dengan adanya penelitian ini dapat menambah pengetahuan tentang disiplin ilmu morfologi yang baik dalam menyusun sebuah wacana. Bagi guru penelitian ini diharapkan dapat bermanfaat sebagai acuan dalam proses pembeljaran wacana yang edukatif sesuai dengan materi yang diajarkan.

Penelitian ini diharapkan juga bermanfaat bagi penelitian lain, yaitu sebagai salah satu bahan pertimbangan penelitian yang masih mempunyai rele-vansi dengan penelitian lain. Dengan harapan penyusunan penelitian selanjut-nya akan menjadi lebih baik lagi. Bagi mahasiswa sebagai calon pendidik, penelitian ini diharapkan bermanfaat sebagai acuan untuk menyusun berita dengan penulisan kalimat yang baik dan benar dan tidak ada lagi kesalahan-kesalahan dalam pemilihan kata dan berita yang dibuat menjadi lebih berkualitas dari segi penulisannya.

\section{DAFTAR RUJUKAN}

Arifin, Zaenal dan Tasai, Amran. 1987. Berbahasa Indonesialah Dengan Benar. Jakarta: PT. Media Tama Sarana Perkasa.

Alwi, Hasan dkk. 1998. Tata Bahasa Baku Bahasa Indonesia. Jakarta: Balai pustaka.

Chaer, Abdul. 2007. Metode Penelitian. Jakarta: Rineka Cipta.

Depdiknas. 2004. Kurikulum Tingkat Satuan Pendidikan SMA Model Silabus

Kelas XI. Jakarta: Badan Standar Nasional Pendidikan. 1989. Kamus Besar Bahasa Indonesia. Jakarta: Balai Pustaka.

http://Gramasatrin-Word.Com/209/04/16Analisis Kesalahan Berbahasa.

http//Pike Keu Nah'u-Wordpress.Com /2009/05/29Analisis Kesalahan

Berbahasa.

Kosasih, E. 2007 . Kompetensi Ketatabahasaan dan Kesusastraan Cermat

Berbahasa Indonesia. Bandung: Yrama Widia.

Keraf, Goris. 2001. Komposisi. Ende Flores : Nusa Indah. 1991. Tata Bahasa. Ende Flores : Nusa Indah.

Mahsun, M.S. 2005. Metode Penelitian Bahasa. Jakarta: PT. Raja Grafindo Persada.

Moleong, Lexy J. 2005. Metode Penelitian Kualitatif. Yogyakarta: Rake Sarasin. Muhajir, Noeng. 2005. Metode Penelitian Kualitatif. Yogyakarta: Rake Sarasin. Putrayasa, Ida bagus. 2007. Kalimat Efektif. Bandung: Refika Aditama.

Prastyaningsih, Luluk Sri Agus. 2001. Ilmu Bahasa (Linguistik). Malang: FKIP Unisma.

Ramlan, M. 1981. Ilmu Bahasa Sintaksis. Yogyakarta: CV Karyono.

Ratna, Kutha. 2004. Metode penelitian. Jakarta. Erlangga

Samsuri. 1985. Analisa Bahasa. Jakarta. Erlangga.

Semi, Atar. 1993. Metode Penelitian Kualitatif. Bandung: Angkasa.

Setyawati. 2010. Analisa Kesalahan Berbahasa Indonesia Teori dan Praktik.

Jakarta: Gramedia Widya Sarana Indonesia.

Soeratno, Siti Chamanah. Tinjauan Atas Asas Relevansi di Dalam

Pembangunan Bangsa. Yogyakarta: Gajah Mada Universiti Prees. 
Supriyadi. 1986. Buku Materi Pokok Analisis Kesalahan Berbahasa. Jakarta: Karunika.

Suryabrata, Sumadi. 1983. Metodologi Penelitian Kualitatif. Bandung: Angkasa. Sudaryanto. 1988. Metode Dan Teknik Analisis Bahasa. Yogyakarta: Duta Wacana

Press. 